\title{
Contention Between English as a Second Language and Special Education Services for Emergent Bilinguals with Disabilities
}

Tensión entre el inglés como segunda lengua y los servicios de educación especial para bilingües emergentes con discapacidades

Tensão entre o inglês como segunda língua e os serviços de educação especial para bilíngues emergentes com deficiências

Solange A. Lopes-Murphy

https://orcid.org/0000-0002-I370-1784

The College of New Jersey, United States of America murphys@tcnj.edu

Received: 29/09/2019

Accepted by peers: 06/02/2020
Sent to peer review: 04/10/2019

Approved: 18/02/2020

DOI: 10.5294/laclil.2020.13.1.3

To reference this article (APA) / Para citar este artículo (APA) / Para citar este artigo (APA) Lopes-Murphy, S. A. (2020). Contention between English as a second language and special education services for emergent bilinguals with disabilities. Latin American Journal of Content \& Language Integrated Learning, 13(1), 43-56. https://doi.org/10.5294/laclil.2020.13.1.3 
ABSTRACT. The debate surrounding the prioritization of services for emergent bilinguals with disabilities is an area in need of attention. The generalized belief that disability-related services must take priority over English as a Second Language services suggests that there is a critical need to develop school professionals' understanding that these learners, in addition to receiving special education services, need substantial support in developing their second language abilities. The steady growth of emergent bilinguals and multilinguals in public schools, that is, students acquiring English as a new language, calls for well-trained practitioners able to meet these students' diverse linguistic, academic, cultural, emotional, and intellectual needs. The typical challenges this population faces acquiring a new language have, well too often, been misrepresented, neglected, or led them to programs for students with true disabilities. However, when emergent bilinguals are legitimately referred to special education, it is not uncommon for their disability-related needs to be prioritized over their English as a Second Language-related needs, and they end up not receiving the support they need to develop social and academic skills in the new language. This review article is intended to stimulate reflection on the types of services being delivered to emergent bilinguals and multilinguals with disabilities in U.S. public school settings.

Keywords (Source: Unesco Thesaurus): emergent bilinguals with disabilities; special education services; special needs education; English as a Second Language services; priority: new language development; language instruction.

RESUMEN. El debate en torno a la priorización de servicios para los bilingües emergentes con discapacidades es un área que requiere atención. La creencia generalizada de que los servicios relacionados con la discapacidad deben tener prioridad sobre los servicios de inglés como segundo idioma sugiere que existe una necesidad crítica de desarrollar la comprensión de los profesionales de la escuela de que estos alumnos, además de recibir servicios de educación especial, necesitan un apoyo sustancial para desarrollar sus habilidades en segunda lengua. El constante aumento de los bilingües y multilingües emergentes en las escuelas públicas, es decir, los estudiantes que adquieren inglés como nuevo idioma, exige profesionales bien capacitados que puedan satisfacer las diversas necesidades lingüísticas, académicas, culturales, emocionales e intelectuales de estos estudiantes. Los desafíos típicos que enfrenta esta población para adquirir un nuevo idioma, con demasiada frecuencia, se han tergiversado, descuidado o llevado a programas para estudiantes con verdaderas dificultades. Sin embargo, cuando los bilingües emergentes son referidos legítimamente a la educación especial, no es raro que sus necesidades relacionadas con las dificultades tengan prioridad sobre sus necesidades relacionadas con el inglés como segunda lengua y terminan por no recibir el apoyo que necesitan para desarrollar habilidades sociales y académicas en el nuevo idioma. Este artículo de revisión busca estimular la reflexión sobre los tipos de servicios brindados a los bilingües y multilingües emergentes con discapacidades en las escuelas públicas de Estados Unidos.

Palabras clave (Fuente: tesauro de la Unesco): bilingües emergentes con discapacidades; servicios de educación especiales; educación especial; servicios de inglés como segunda lengua; prioridad; desarrollo de una nueva lengua; enseñanza de idiomas.

RESUMO. O debate em torno da priorização de serviços para os bilíngues emergentes com deficiências é uma área que requer atenção. A crença generalizada de que os serviços relacionados à deficiência devem ter precedência sobre os serviços de inglês como segunda língua sugere que há uma necessidade crítica de desenvolver a compreensão dos profissionais da escola de que esses alunos, além de receber serviços de educação especial, precisam de apoio substancial para desenvolver suas habilidades na segunda língua idioma. O aumento constante de bilíngues e multilíngues emergentes nas escolas públicas, ou seja, estudantes que adquirem inglês como uma nova língua, exige profissionais bem treinados que possam atender às diversas necessidades linguísticas, acadêmicas, culturais, emocionais e intelectuais desses alunos. Com muita frequência, os desafios típicos enfrentados por essa população na aquisição de uma nova língua foram tergiversados, descuidados ou levados a programas para estudantes com dificuldades reais. No entanto, quando os bilíngues emergentes são legitimamente indicados para educação especial, não é incomum que suas deficiências relacionadas tenham precedência sobre suas necessidades relacionadas ao inglês como segunda língua e acabam não recebendo o apoio necessário para desenvolver habilidades sociais e acadêmicas na nova língua. Este artigo de revisão procura estimular a reflexão sobre os tipos de serviços prestados aos bilingues e multilíngues emergentes nas escolas públicas dos Estados Unidos.

Palavras-chave (Fonte: tesauro da Unesco): bilíngues emergentes com deficiência; serviços de educação especial; educação especial; serviços de inglês como segunda língua; prioridade; desenvolvimento de uma nova linguagem; ensino de línguas. 
It is widely known that the number of emergent bilinguals and multilinguals in United States (U.S.) schools has increased substantially over the past several decades. However, it is worrisome that a growing number of this student population is being identified as having a disability. In 2003, the English language learning population identified as having an intellectual, psychological, or physical disability accounted for $8.4 \%$ of the non-native population in American public-school classrooms (Kangas, 2014). This figure has jumped to $14.7 \%$ in recent years, according to the 2017 National Center for Educational Statistics. The $75 \%$ increase in emergent bilinguals with disabilities in academic contexts calls for careful examination of the types of instructional services these students ought to receive. Studies on the academic experiences of emergent bilinguals with disabilities are limited (Thurlow et al., 2016), mostly due to the diversity of their profiles and needs, and of the approaches used by school settings to identify, label, and place them in special education classrooms. However, the few studies available reveal that there is a tendency for the learner's disability needs to take priority over their second language needs (Kangas, 2014), resulting in the neglect of the latter.

The under- and over-representation of emergent bilinguals in special education programs remains a reality in U.S. public schools and needs urgent attention (Artiles \& Ortiz, 2002; Barrio, 2017; Baseggio, 2018; Kena et al., 2014; Klingner et al., 2005; Linn \& Hemmer, 2011; Ortiz, 2014; Sullivan, 2011). The largest group of students referred to special education services, about 33\%, are those with Specific Learning Disabilities (SLDs), that is, insufficient understanding and ability to use the language, both verbal and written (National Center for Education Statistics, 2020). Such a profile also characterizes those in their initial stages of acquisition in a new language, which makes SLD categories subjective when assessing emergent bilingual and multilingual students for disabilities (WIDA, 2017).

Ideally, the multiple needs of emergent bilinguals and multilinguals with disabilities should be addressed through a balanced and integrated approach (Kangas, 2014). However, the insufficient understanding of language acquisition among professionals (Okhremtchouk \& Sel- 
lu, 2019) and the misconception that "special education trumps ESL" (Kangas, 2014) may contribute to the misplacement of these students, the prioritization of services delivered to them, and the hindrance of acquisition of the new language. This paper explores the intersection of language acquisition and learning disability as a framework for addressing these issues and calls for an approach that recognizes both the language and special needs of this population. It capitalizes on the debate that exists among school professionals over what constitutes services of priority for this population and explores the multiple needs that emergent bilinguals and multilinguals have. This review addresses the persistent under- and over-representation of emergent bilinguals in special education, the evaluation process for special education services, and the current contexts of special education services as far as promoting second language development. The article discusses the value of professionals' collaboration and shared expertise on student learning, and it proposes instructional recommendations to address both disability and the ESL-related needs of each learner and to support emergent bilinguals' linguistic, social, academic, intellectual, and emotional development.

\section{Evaluation of emergent bilinguals for special education}

Acquiring a new language is a daunting process and challenges the learner in multiple ways. Difficulties related to comprehending messages in the new language, following directions, and meeting communicative and academic expectations are considered natural struggles most language learners face when developing proficiency in a new language. However, some of those struggles extend themselves beyond what is considered typical; that is, they persist despite all instructional supports or modifications used in the classroom to promote learning. In those instances, it is possible that struggles are either caused by external circumstances that delay the learning process for the learner or caused by internal factors, that is, a within-child condition that prevents the learner from experiencing successful learning. 
Separating a learner's struggle acquiring the new language from a possible disability is not an uncomplicated task (Hamayan et al., 2013). This complexity is due to the multitude of causes that may affect learners in different ways. Examples include circumstances that led to immigration to the U.S., home context, level of literacy in the native language, and readiness for academic work. Exploring such factors closely is beneficial because it helps contextualize students' classroom behaviors and produces a clearer understanding of students, which, in turn, decreases the probability that an emergent bilingual will be inappropriately evaluated for special education.

When school professionals suspect that an emergent bilingual has a disability, they should adopt a multi-layered approach so that all possible external factors that might impact a learner's behaviors and learning experience can be explored and evaluated (Klingner \& Eppolito, 2014). The more professionals learn about the cultural, linguistic, and disability profiles of a learner, the better they can identify the source of a learner's struggles and determine whether those are caused by the acquisition of the new language, a disability, or both. Only then will professionals be able to identify and deliver the academic services that students ultimately need.

The insufficient knowledge of school professionals on the process of second-language acquisition has made emergent bilinguals vulnerable; that is, they are either positioned as individuals with disabilities only or viewed as needing only language support (Kangas, 2014; Okhremtchouk \& Sellu, 2019; Samson \& Lesaux, 2009). Such a binary approach has damaging consequences for placement. Emergent bilinguals in the elementary grades tend to be approximately 30\% more likely to be evaluated for special education services compared to mainstream students in the earlier grades (Samson \& Lesaux, 2009), and this figure increases for middle and high school emergent bilinguals (Artiles et al., 2005).

Emergent bilinguals in initial stages of new language development tend not to be considered for special education services (Kangas, 2014; Samson \& Lesaux, 2009), and evaluation for special education services are delayed until they are sufficiently proficient in English. In those instances, their language needs to take priority over a possible disability need, which results in their under-representation in special 
education classrooms. However, when emergent bilinguals reach third or fifth grade (Samson \& Lesaux, 2009; Artiles et al., 2005), that is, once they have gained sufficient proficiency in the new language, they tend to be over-referred for special education services.

Approaches to evaluating an emergent bilingual for disabilities tend to be inequitable. The over-reliance on test scores during the special education referral process (Klingner \& Harry, 2006) reveals how unbalanced and biased the process can be. Factors that pertain to the child's second language acquisition, acculturation process, instructional context, and instructional practices tend to be disregarded during the child's evaluation. A number of researchers (Klingner \& Eppolito, 2014; Rueda \& Windmueller, 2006) have claimed consistently that environmental factors surrounding the learner can directly affect classroom behaviors and academic performance. For that reason, investigating both external and internal factors that may affect an emergent bilingual's learning is a must.

\section{Meeting the multiple needs of emergent bilinguals and multilinguals with disabilities}

Services delivered to emergent bilinguals with disabilities must integrate both the child's ESL- and disability-related needs (Kangas, 2014). An emergent bilingual with disabilities must be provided with both types of services to support their language, literacy and disability needs. In contexts where emergent bilinguals are overrepresented in special education, special education services tend to be regarded as a priority over ESL services, which suggests that ESL is less legally significant than special education services. In those contexts, their ESL-related needs are ignored. Conversely, in contexts where emergent bilinguals are underrepresented in special education, they tend to be positioned as individuals with ESL-related needs only. As a result, their disability-related needs tend to be neglected. Prioritizing services for emergent bilinguals or determining that one service is of more significance than the other implies that the multiple needs that characterize emergent bilinguals with disabilities are ignored. 
Although the language proficiency of emergent bi- and multilinguals with disabilities may influence the weight given to language and special needs, it is most common for the learner's disability needs to take priority over their second language (Kangas, 2014). Despite legislation to ensure that all emergent bilinguals receive language services, ESL programs in U.S. K-12 public schools tend to be regarded as "less legally significant" (Kangas, 2014, p. 299) when compared to those focused on addressing the special needs of students, and, as a result, have lower status. It is, then, not uncommon for class schedules for emergent bilinguals with disabilities to be configured in a way that prevents them from receiving ESL and special education supports simultaneously, resulting in them receiving mainly special education support and little to no support in developing the new language. Special education professionals serving emergent bilinguals tend to capitalize on instructional interventions that address only their disabilities and not their ESL-related needs. Their insufficient training in second language acquisition and culturally sustaining practices (Gay, 2002; Okhremtchouk \& Sellu, 2019) plays a significant role in the instructional practices emphasized. It is critical that professionals appreciate that, whether an emergent bilingual has low English-language needs and high disability-related needs or high English-language needs and low disability-related needs, such students will benefit from support to develop and grow in the new language, in addition to other available supports. The misconception that special education takes priority over ESL must be dispelled.

Holding lower expectations for emergent bilinguals in general is another attitude that compromises students' academic performance settings (Goulah \& Soltero, 2015). The general perception that emergent bilinguals are deficient is a sad reality in public school. Such low expectations become even lower once these students are placed in special education (Gaviria-Soto \& Castro-Morera, 2005). Special education programs have historically emphasized a segregated system aimed at supporting primarily the cognitive deficiencies of a child (Artilles et al., 2010). The further alienation that such programs create (Klingner et al., 2005) jeopardizes an emergent bilingual's development in the second language and reduces their opportunities to interact with individuals from mainstream settings. 
Researchers maintain that approximately $10 \%$ of the emergent bilingual population is affected by a legitimate disability (Zehler et al., 2003); therefore, there is an urgent need for special educators to receive solid training and professional development in second-language acquisition and cultural issues so that emergent bilinguals with disabilities are given all the opportunities they deserve to have both their disability and ESL-related needs met.

\section{The need for collaborative efforts and integrated services}

The benefits of collaborative partnerships among school professionals have been strongly emphasized by researchers (Ferguson et al., 2013). Specifically, in contexts characterized by the differing linguistic and cultural backgrounds of people, it is crucial that collaborative teams include professionals trained in culturally sensitive and equitable practices (Hamayan et al., 2013). These individuals can serve as cultural brokers, professionals who possess the ability to function in bilingual/ multilingual and bicultural/multicultural contexts with the purpose of facilitating cross-cultural communication and promoting collaborative initiatives (Jejewski \& Sotnik, 2001). ESL teachers can unquestionably serve as cultural brokers in decisions regarding what services emergent bilinguals, both those with and without disabilities, should receive. Their understanding of second-language development and diverse cultural practices enables them to identify the specific ESL-related services that would benefit emergent bilinguals with disabilities. Purposeful and intentional efforts to involve these cultural brokers in conversations about these learners would potentially increase the infusion of inclusive educational supports that are linguistically and culturally sensitive. An example of such collaborative practice would be during Individualized Education Program (IEP) meetings. These are instances where the presence of language specialists is unarguably critical to prevent an emergent bilingual from being inappropriately referred to special education (Hamayan et al., 2013). The presence of an advocate who understands the different linguistic and cultural con- 
texts affecting the student will bring attention to the multiple needs of emergent bilinguals with disabilities and include services in their IEPs that address both their disability and ESL-related needs.

\section{Integrated pedagogical practices: recommendations}

The awareness that behaviors associated with acquiring a new language can be similar to those associated with learning disabilities (Klingner \& Eppolito, 2014) is essential for all school professionals, particularly as they identify the types of services to support the academic growth of emergent bilinguals with disabilities. The ideal pedagogical approach for emergent bilinguals with disabilities would be one that infuses practices that support both the learner's ESL-related needs and their disability needs (Short et al., 2018; Virginia Department of Education, 2017). Such practices would be consistently and intentionally emphasized in both ESL and special education settings to support students' multiple needs, and would include:

1. Multimodal representation of a concept during instruction: Emergent bilinguals with disabilities benefit from instruction that integrates listening, speaking or showing, seeing or reading, writing, tactile elements to support learning, and Total Physical Response (TPR) or Teaching Proficiency through Reading and Storytelling (TPRS).

2. Multiple means of expression: It is beneficial to emergent bilinguals with disabilities to be able to demonstrate their knowledge of the content or understanding of a word or skill through nonverbal, as well as verbal, forms of expressions. Some examples are expression through pictures, words, gestures, collages, demonstrations, etc.

3. Sufficient wait time or processing time: Students learning a new language need at least twice as long as native speakers to process input in the new language. Once solicitations are posed, it is critical that teachers wait between 9-24 seconds before calling on students to respond to questions in class. Emergent bilinguals with disabilities may also take twice as long as those without disabilities to read in the target language. 
4. Images to build meaning and support comprehension: Lessons should highlight the most critical nouns and verbs and embed images that support comprehension of those items and central message.

5. Activation of prior knowledge: Brainstorms associated with the main topic of the lesson can support vocabulary development of emergent bilinguals with disabilities and associate the topic with previously experienced situations.

6. Intentional repetition of key words and phrases: Identifying the key words, concepts, and phrases and capitalizing on those intensively during instruction are important strategies to support emergent bilinguals with disabilities in building vocabulary in the new language.

7. Use of sentence frames, sentence starters, and formulaic expressions: Whether in an ESL or in a special education academic context, supporting language production through sentence frames, sentence starters, and formulaic expressions is key to stimulating learners' self-expression and oral language development.

8. Use of fidget toys or stress management devises: Providing such toys to emergent bilinguals with disabilities can help them regulate some of the emotional influences on their learning.

9. Use of colored transparency overlays: The lighting in the room can affect how learners perceive written information. Colored overlays can help relax emergent bilinguals' eyes, neck and shoulders while reading or working on reading fluency development activities.

10. Use of different color paper for student work: Research has revealed that learning from printed material can be influenced by its color. For emergent bilinguals with attention deficit/hyperactivity disorder (ADHD), the color purple was found to be the one that helps these students focus (Virginia Department of Education, 2017).

11. Font selection \& document formatting: Different font types can have an impact on emergent bilinguals' ability to comprehend text. Provide your emergent bilinguals with a document with ten common fonts of various sizes to determine whether font readability is a consideration for them.

12. Assistive technology: Emergent bilinguals with disabilities may benefit from digital voice recorders, electronic spellers, books on tape and digital books, computer programs that allow words to be read 
aloud, text-to-speech software, language software and applications, translation portals, and recording pens.

\section{Conclusion} Therefore, it is key that teachers support the development of the new language while addressing students' disabilities (Kangas, 2014). Finally, to support emergent bilinguals with disabilities fully, it is important to understand the consequences of prioritizing the services they receive and to explore the impact that those priorities will have on the learner's language and academic trajectories, as well as their disability.

\section{References}

Artiles, A. J., Kozleski, E. B., Trent, S. C., Oscher, D., \& Ortiz, A. (2010). Justifying and explaining disproportionality, 1968-2008: A critique of underlying views of culture. Exceptional Children, 76(3), 279-299. https://doi.org/10.1177/001440291007600303

Artiles, A. J., \& Ortiz, A. A. (2002). English language learners with special education needs: Identification, assessment, and instruction. Delta Systems.

Artiles, A. A., Rueda, R., Salazar, J. J., \& Higareda, I. (2005). Within-group diversity in minority disproportionate representation: English language learners in urban school districts. Exceptional Children, 71(3), 283-300. http://citese- 
erx.ist.psu.edu/viewdoc/download?doi=10.1.1.524.3956\&rep=rep1\&type $=p d f$

Barrio, B. L. (2017). Special education policy change: Addressing the disproportionality of English language learners in special education programs in rural communities. Rural Special Education Quarterly, 36(2), 64-72. https://doi.org/10.1177/8756870517707217

Bassegio, K. (2018). A silent crisis: The misidentification of English language learners as students with learning disabilities. All Regis University Theses, 865. https://epublications.regis.edu/theses/865/

Ferguson, D., Hanreddy, A. N., \& Ferguson, P. M. (2013). Finding a voice: Families' roles in schools. In L. Florian (Ed.), The SAGE handbook of special education (pp. 763-783). Sage.

Gargiulo, R. M. (2012). Special education in contemporary society: An introduction to exceptionality. Sage.

Gaviria-Soto, J. L., \& Castro-Morera, M. (2005). Beyond over-representation: The problem of bias in the inclusion of minority group students in special education programs. Quality and Quantity, 39, 537-558. https://doi.org/10.1007/s11135-005-1606-3

Gay, G. (2002). Culturally responsive teaching in special education for ethnically diverse students: Setting the stage. Qualitative Studies in Education, 15, 613-629. https://doi.org/10.1080/0951839022000014349

Goulah, J., \& Soltero, S. (2015). Reshaping the mainstream education climate through bilingual-bicultural education. In Research on Preparing Inservice Teachers to Work Effectively with Emergent Bilinguals (Advances in Research on Teaching, Vol 24) (pp. 177-203). Emerald Group Publishing Limited. https://doi.org/10.1108/S1479-368720150000024009

Hamayan, E., Marler, B., Sánchez-López, C., \& Damico, J. (2013). Special education considerations for English language learners: Delivering a continuum of services ( $2^{\text {nd }}$ Ed.). Caslon Publishing.

Jezewski, M. A., \& Sotnik, P. (2001). Culture brokering: Providing culturally competent rehabilitation services to foreign-born persons. Center for International Rehabilitation Research Information and Exchange. http://cirrie.buffalo.edu/culture/ monographs/cb.php

Kangas, S. E. N. (2014). When special education trumps ESL: An investigation of service delivery for ELLs with disabilities. Critical Inquiry in Language Studies, 11(4), 273-306. 
Kena, G., Aud, S., \& Johnson, F. (2014). The condition of education 2014. http://nces.ed.gov/pubs2014/2014083.pdf

Klingner, J. K., Artiles, A. J., Kozleski, E., Harry, B., Zion, S., Tate, W., Durán, G. Z., \& Riley, D. (2005). Addressing the disproportionate representation of culturally and linguistically diverse students in special education through culturally responsive educational systems. Education Policy Analysis Archives, 13(38), 1-40. https://doi.org/10.14507/epaa. v13n38.2005

Klingner, J., \& Eppolito, A. M. (2014). English language learners: Differentiating between language acquisition and learning disabilities. Council for Exceptional Children.

Klingner, J. K., \& Harry, B. (2006). The special education referral and decision-making process for English language learners: Child study team meetings and placement conferences. Teachers College Record, 108(11), 2247-2281. https://nepc.colorado.edu/sites/default/files/ publications/10.1.1.548.1121.pdf

Linn, D., \& Hemmer, L. (2011). English language learner disproportionality in special education: implications for the scholar-practitioner. Journal of Educational Research and Practice, 1(1), 70-80. http://doi.org/10.5590/ Jerap.2011.01.1.06

National Center for Education Statistics. (2017). The condition of education 2017. https://nces.ed.gov/pubsearch/pubsinfo.asp?pubid=2017144

National Center for Education Statistics. (2020). Students with disabilities. https://nces.ed.gov/programs/coe/indicator_cgg.asp

Okhremtchouk, I. S., \& Sellu, G. S. (2019). Teacher readiness to work with English language learners: Arizona context. Teacher Educator (2), 125144. https://doi.org/10.1080/08878730.2018.1533058

Ortiz, S. O. (2014). Disproportionality and English language learners in special education: Why it happens and what to do about it [PowerPoint slides]. http://esc9.courseinsite.com/file_attachments/3111.pdf

Rueda, R., \& Windmueller, M. P. (2006). English language learners, LD, and overrepresentation: A multiple-level analysis. Journal of Learning Disabilities, 39(2), 99-107. https://doi.org/10.1177/00222194060390020801

Samson, J. F., \& Lesaux, N. K. (2009). Language-minority learners in special education: Rates and predictors of identification for services. Journal of Learning Disabilities, 42(2), 148-162. https://doi. org/10.1177/0022219408326221 
Short, D. J., Becker, H., Cloud, N., Hellman, A. B., \& Levine, L. N. (2018). The 6 principles for exemplary teaching of English learners. TESOL Press.

Sullivan, A. L. (2011). Disproportionality in special education identification and placement of English language learners. Council for Exceptional Children, 77(3), 317-334. http://debdavis.pbworks.com/w/file/ fetch/81120626/journal\%202.pdf

Thurlow, M. L., Christensen, L. L., and Shyyan, V. V. (2016). White paper on English language learners with significant cognitive disabilities. University of Minnesota, National Center and Educational Outcomes, English Language Proficiency Assessment for the $21^{\text {st }}$ Century.

Virginia Department of Education. (2017, January). Supporting world language learning for students with disabilities. Office of Special Education Instructional Services, Office of Humanities and Early Childhood. http://www.doe.virginia.gov/instruction/foreign_language/resources/world-language-swd.pdf

WIDA. (2017, May). Identifying ELLs with specific learning disabilities: Facts, advice, and resources for school teams. https://wida.wisc.edu/sites/default/files/resource/FocusOn-Identifying-ELLs-with-Specific-Learning-Disabilities.pdf

Zehler, A. M., Fleischman, H. L., Hopstock, P. J., Stephenson, T. G., Pendzick,

M. L., \& Sapru, S. (2003). Descriptive study of services to LEP students and LEP students. https://www.ncela.ed.gov/files/rcd/BE021199/special_ed4.pdf 